\author{
ANNA KOLASIŃSKA \\ Pedagogical University of Krakow, Poland
}

\title{
Opportunities for the Development of Film Tourism in Kraków
}

\begin{abstract}
For several years film tourism has been perceived as a new trend in cultural tourism. Following this trend, this work aims to determine which forms of film tourism are currently developing in Kraków. Moreover, it wants to indicate the potential of the city to create a tourism product in this field. In the research, guidebooks, as well as film materials and internet sources, have been used. Moreover, the offer of Kraków travel agencies regarding organised guided tours based on film have been analysed, along with sources such as city council strategic documents and reports. The research has demonstrated that Kraków is a city with high tourist potential in those terms. It regards both film production (including its surrounding area) and organisation of film festivals. However, analysis of guidebooks and local travel agency offers has pointed to a low interest in film. The research presented in the article, due to its attempt at comprehensiveness and upto-dateness in the context of new ideas for the development of tourism products, constitutes a contribution to Polish literature on cultural tourism. In practical terms, it may become an inspiration for those who are responsible for creating tourism products based on Kraków's film heritage.
\end{abstract}

Keywords: film festival; film location; film tourism; Kraków; movie tourism

Received: 18 December 2019

Accepted: 30 April 2020

Suggested citation:

Kolasińska, A. (2020). Opportunities for the Development of Film Tourism in Kraków. Prace Komisji Geografii Przemysłu Polskiego Towarzystwa Geograficznego, 34(3), 53-66. doi: 10.24917/20801653.343.4

\section{INTRODUCTION}

Film tourism as a form of cultural tourism is considered one of the most dynamic directions for tourism development in the last decade (Kim, Reijnders, 2017) and is becoming a phenomenon of global significance (Cardia et al., 2019). Until recently, however, it had been considered just another form of niche tourism (Faber, Tomala, 2011). Film productions increasingly affect the image of cities and regions and are a tool for their promotion (Marczak, 2012). The recent discussion on this type of tourism has focused on Western Europe. However, this interest increasingly applies to the cities of Central and Eastern Europe, too (Ciszewska, 2016). Poland is not one of those countries which have made film tourism a branded product unlike New Zealand in which The Lord of the 
Ring was filmed (Buchmann et al., 2010) or the United Kingdom from Harry Potter (Lee, 2012). Neither does it use film tourism for marketing activities like Australia, USA and South Korea (Connell, 2012). Analysing the Polish literature, however, it can be seen that on the one hand the use of film as a magnet for attracting tourists to specific places, and on the other for creating local tourist attractions based on film, is visible in the tourism industry. Tourists are looking for new ways to explore tourism destinations, especially in situations when they are revisiting the place for the second time. Themed sightseeing routes related to film, the history of cinematography and outstanding film characters are becoming an alternative to the traditional form of sightseeing. They show not only places in a different context, but also lead to the sites overlooked by the most popular sightseeing routes. In addition to exciting film locations worth visiting, film festivals are held in many Polish cities. These have become a recognisable brand for those cities and gather a broad audience annually (including the Polish Feature Film Festival in Gdynia, Warsaw International Film Festival, Kraków Film Festival, the 'Tofifest' International Film Festival in Toruń, and the 'Two Riversides' Film and Art Festival in Kazimierz Dolny). Although the organisation of film festivals in Poland has a tradition lasting several decades, it has only been since the 1990s that they have ceased to be mainly a meeting place for the industry and have become events that attract tourists as well (Zmyślony, 2001). According to Konieczna (2014), participation in a festival is associated with multi-dimensionality in travel and the need to contact cultural heritage by visiting places otherwise attractive to tourists.

When considering Polish initiatives in film tourism, Łódź should be mentioned as it belongs to the Creative Cities Network as a City of Film (the only such city in Poland) with the Łódź Walk of Fame and the Łódź Fairy Tale Trail (Ciszewska, 2016); and Sandomierz in which, since the broadcast of the TV series Ojciec Mateusz (Father Mateusz) in 2008, tourism has increased significantly (Szpara, 2016). Another is the only open-air film museum which is in the village of Cichowo (Wielkopolska) based on Allan Starski's screenplay for the Andrzej Wajda's film Pan Tadeusz. Also noteworthy are On the Film Reel, a film route in Piotrków Trybunalski, and Film Łódź (Kronenberg, 2016), as well as the official Torun Film Route, opened in 2017 and emphasising the relationship between the townscapes of Torun, and those who came from this city and were involved with the development of Polish cinema. Besides these, other initiatives were undertaken to develop this form of tourism include Polska na filmowo, a guidebook dedicated to film tourists by Szymański in 2010 providing information on where well-known films and TV series were shot with selected film locations and including foreign productions.

Kraków also has its film heritage. It was here in 1896 that the first film screening in Poland using the cinematograph of the Lumière brothers took place at the Juliusz Słowacki Teatr Miejski (Malewski, 1996). After World War II Za króla Kraka directed by Zenon Wasilewski, the first professional animated film for children was made with a script based on the Wawel Dragon, the most famous Kraków legend. Contemporary Kraków is often chosen by film and TV serial screenwriters. Its unique buildings represent almost all architectural styles, from the picturesqueness of the Old Town contrasted with the severity of Nowa Huta or Podgórze. As a result, Kraków is available for various film genres including romantic comedies, such as Don't Lie, Baby (Nie kłam, kochanie) and Angel in Kraków (Anioł w Krakowie); detective stories, e.g. Entanglement (Uwikłanie); biographical films, for example, Karol: A Man Who Became Pope (Karol. Człowiek, który został papieżem); or war-related, for instance, Katyń and Schindler's List 
(Lista Schindlera). In the last decade, interest in Kraków locations among Indian film producers has been noticed too. The outstanding Polish director Andrzej Wajda was associated with Kraków and donated his film awards, an Oscar, the Golden Palm from Cannes and the Venetian Golden Lion, to the Jagiellonian University. A temporary exhibition in the main building of the National Museum in Kraków was devoted to his work. Kraków is a city of festivals related to film art in the broadest sense and is undeniably a city with many cultural values which testify to its excellent tourist potential without the need for additional promotion on the part of film art. However, the development of film tourism is a response to the new needs and interests of tourists that can be observed in the tourism market.

In the Polish literature, relatively few works deal with the theme of film tourism, and those few usually relate only to selected aspects (e.g. film festivals or identification of film locations). However, in the literature on tourism in Kraków, film does not appear at all. The attempt by the present author to take a broader look at this form of tourism may contribute to a further and more thorough analysis.

The purpose of this article is to recognise the state of development of film tourism in Kraków, as well as to indicate the city's potential to create a new tourism product. The following research questions were asked:

1. Is film tourism present in the city council's primary strategic documents on the development of tourism in Kraków?

2. Is there any content on film tourism in Kraków's guidebooks and publicly available promotional materials?

3. Do local travel agencies offer film tours around Kraków?

4. What are the prospects for the development of film tourism in Kraków?

\section{FILM TOURISM - DEFINITION}

Film tourism includes both films and film production associated with the specific geographical space of a place or region, or the location of a film production studio, or other features associated with film or TV (Beeton, 2005). It is worth noting that in the foreign literature the term 'film tourism' can be expressed in other ways, often interchangeable, for example with 'movie tourism' which often refers to early American cinematography (Connell, 2012). 'Screen tourism' has a slightly different tone, covering a wide range of phenomena associated with film and television (Connell, Meyer, 2009) while 'film-induced tourism' is a relatively narrow definition referring to tourist visits which are stimulated by locations appearing in films. A term used more often in the tourism industry (e.g. in travel agencies) than in the literature is 'set-jetting', the visiting of real locations of films (including TV series) and the places they immortalise (Joliveau, 2009).

In Polish literature, film tourism is defined by Stasiak (2009), who separates 'biographical tourism' and film 'fiction tourism'. 'Biographical tourism' is associated with visiting biographical museums and exhibitions dedicated to famous actors, directors and places related to their work. According to Stasiak, this form of tourism includes participation in film festivals. On the other hand, film 'fiction tourism' manifests itself in travelling in the footsteps of film protagonists, searching for film locations, participating in various film workshops, or spending time in film theme parks. When considering the development of film tourism, the positions of other researchers who classify film tourism differently should also be cited (Beeton, 2016; Connell, 2012; Tucki, 
2016; Urbańczyk, 2019). These include, among others, 'on-location tourism', in which the place associated with a film is the purpose of a journey or becomes the overriding theme of a holiday. There is also a form here that has not been seen in Poland, namely involving trips to see the homes of movie stars or directors (e.g. in Hollywood). Other forms of film tourism are 'commercial on-location' (guided tours of film locations); 'commercial off-location' (visits to studios) along with visits to movie theme parks such as Hengdian World Studios known as 'Chinawood' (Connell, 2012), and 'film event tourism' by participation in film festivals or film premieres.

\section{MATERIALS AND METHODS}

In the research, secondary source analysis was carried out. Strategic planning documents were analysed, including the Kraków Tourism Development Strategy for 20142020 and reports on its implementation. Specialist foreign and Polish literature on film after 2000 as well as Kraków guidebooks were examined for film content. These were prepared based on the bibliography for Małopolska and Kraków available in the Voivodeship Public Library in Kraków, while items published in 2005-2019 on sightseeing in Kraków, including the districts of Podgórze, Nowa Huta and Kazimierz, were taken into account. This investigation covered 40 items published between 2005 and 2019. Earlier years were not taken into account because film tourism has only been discussed since 2005 when Beeton's 'Film-Induced Tourism' was published, that is the first book dedicated to it. It should be borne in mind, however, that in earlier years, researchers emphasised that film and television may have an impact on the selection of tourism destinations (Riley et al., 1998 after Tucki, 2016).

Furthermore, an analysis of current promotional materials published by Kraków city council was made, as well as of content from leading websites on tourism in Kraków. In order to check opportunities to visit 'film' Kraków with a professional guide, the offers of tourism organisers were analysed. This issue was investigated using the register of tourism organisers and entrepreneurs facilitating the purchase of related tourist services of the Marshal of Małopolskie Voivodeship (Rejestr Organizatorów Turystyki... 2019). In order to identify film festivals taking place in Kraków, film literature was used: Magazyn filmowy - the monthly magazine of the Polish Filmmakers Association, the monthly Kino - devoted to film creation and education, as well as online sources in the form of official festival pages. The use of the online Polish film database filmpolski. $p l$ created by the Film School in Łódź, and the Fototeka service presenting the photographic resources of the National Film Archive's 'Audio-visual Institute' on the history of Polish film, enabled the main film locations of Kraków to be identified.

\section{RESULTS}

\section{Film tourism in strategic documents}

Film and film heritage, together with literature, were included in the official strategic document for Kraków: Strategy for Tourism Development 2014-2020 as part of the implementation of the task 'Kraków as a protagonist: film and literary tourism', itself part of a broader strategic concept of 'Creating new tourism products'. The document states that "there have recently been significant development opportunities in Kraków and its region for film productions" (Wilkońska, Rotter-Jarzębińska, 2019: 43). Besides, 
Kraków's film heritage has been recognised as a city resource with untapped potential for development in the Strategy... entitled 'City Sightseeing'. The vision of Kraków contained in the Strategy... assumes that in 2020 Kraków will be recognisable on a European scale as a 'City of festivals and large-scale events'. Although the vision presented does not have a direct reference to film tourism, in the context of the definition cited earlier, it can be assumed that the numerous film festivals are included in film tourism events. While analysing reports on the implementation of the Strategy... for 2015-2018, it should be stated that as part of the task 'Kraków as a protagonist: film and literary tourism', the film section identified the activities of the Kraków Film Commission, the Regional Film Fund and the International Film Fund.

The primary task of the Kraków Film Commission, an institution established in 2008, is to promote Kraków and Małopolskie Voivodeship as a film location, as well as to give direct assistance in the organisation of specific film locations (permits, contacts with the local audio-visual industry). The Regional Film Fund, established in 2009, financially supports, through a competition, film productions related to Kraków and Małopolskie which may contribute to the tourist promotion of the region. The competition's budget consists of funds obtained from Małopolskie Voivodeship and Kraków itself. The International Film Fund is a tool created in 2015 whose task is to support international co-productions created with a view to international cinema distribution.

\section{Film tourism in tourist guidebooks and promotional materials}

Based on an analysis of guidebook content, this was divided into three categories. In the first (I) were guidebooks with a proposed sightseeing route related to a film or those without a route but with an extended description of films made in Kraków (usually a dozen or so sentences). In the second category (II) were those with a brief mention of a film (usually 2-3 sentences), while in the third (III) no reference to any film shot in Kraków was found. Detailed percentage distribution of the share of individual categories is presented in Figure 1.

Figure 1. Content related to film tourism in Krakow guidebooks

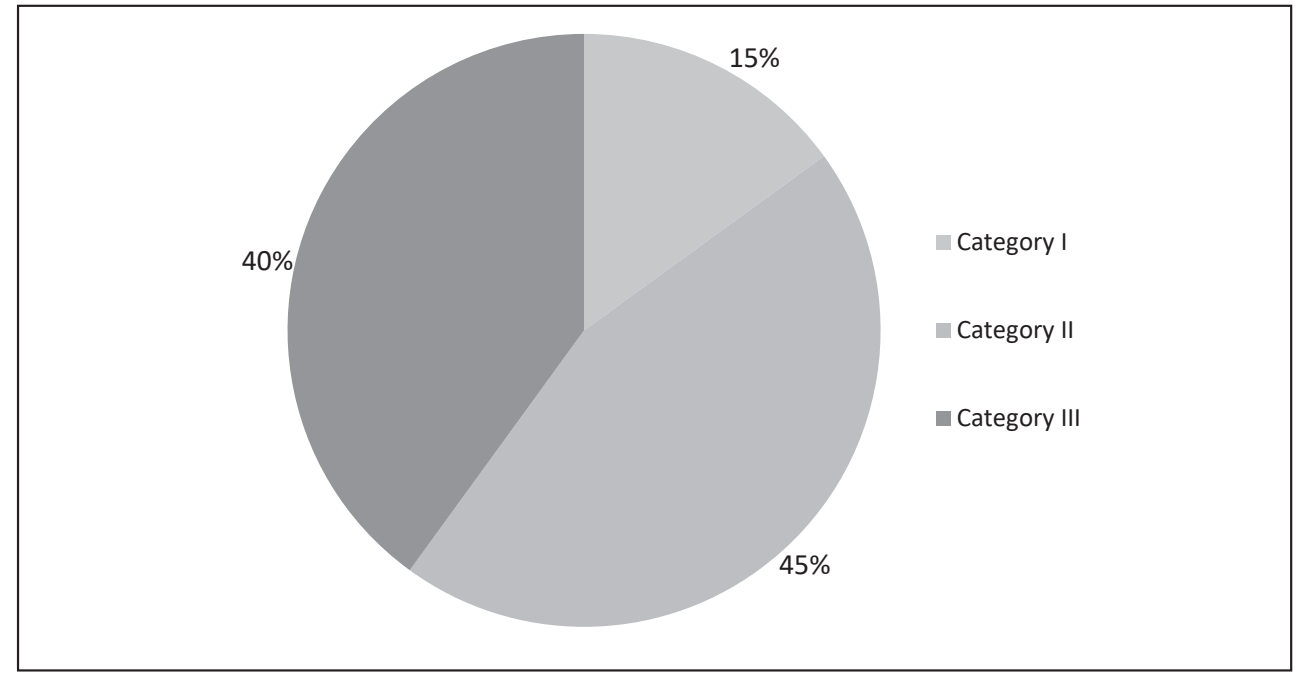

Source: own study 
Category I guidebooks (15\%) included those suggesting visiting Kazimierz and Podgórze to follow in the footsteps of Steven Spielberg's film Schindler's List (Lista Schindlera), as well as those in which filming in Kraków was given more attention. There were films such as Man of Marble (Człowiek z marmuru) by Andrzej Wajda, Double Life of Veronica (Podwójne życie Weroniki) by Krzysztof Kieslowski, Brother of our God (Brat naszego Boga) by Krzysztof Zanussi, Angel in Kraków (Anioł w Krakowie) by Artur Więck and Witold Beres, and the comedy Vinci by Juliusz Machulski. Guidebooks from category II (40\%) mention film locations concerning Kazimierz and Podgórze. These included Liban Quarry where Allan Starski built the sets for the Oscar-winning Schindler's List (Lista Schindlera). In the case of Kazimierz, one of the guidebooks also includes the film Nights and Days (Noce $i$ dnie) directed by Jerzy Antczak. In this film Kraków's Kazimierz district (around Plac Nowy) was used for scenes of the fire in Kaliniec. In guidebooks about Nowa Huta, some information about Piotr Ożarski, the prototype for Andrzej Wajda's man of marble, has appeared.

For analysis of the content of official advertising materials issued by Kraków city council on the opportunity to explore the city through film, 25 current leaflets available at Tourist Information Points as well as online, were used. Only five of them (16\%) included information on films shot in Kraków: Nowa Huta Guidebook, 3 days in Kraków, Only in Kraków, Kraków City Break and Guidebook to Podgórze. In four of them, this concerned Schindler's List (Lista Schindlera), while the leaflet about Nowa Huta mentions Piotr Ożarski, the famous 'leading worker', whose character became the prototype for Mateusz Birkut - the hero of Man of Marble (Człowiek z marmuru).

In terms of the content of tourist and information websites, it was found that only one of them prepared a route referring to film. It is the portal www.Kraków.travel, established in 2009 and operated by the Kraków Festival Office. Its content is presented in seven languages. The tour section proposes two routes: 'Film Kraków' (2019) and 'In the Footsteps of Schindler's List' (2019). Both routes have been prepared in such a way that everyone using this website can navigate them independently (a map with sites along the route is attached and supplemented with photographic material).

\section{A GUIDED FILM TOUR OF KRAKÓW: ANALYSIS OF AVAILABILITY}

The analysis of the availability of guided services devoted to film in Kraków was based on the register of tourism organisers and entrepreneurs facilitating the purchase of related tourist services of the Marshal of Małopolskie Voivodeship (Rejestr Organizatorów Turystyki... 2019), which contains 638 names. As a result of the analysis, 73 organisers offering services for tourism to Kraków and having an up-to-date offer on the internet were listed. Out of these, only $7 \%$ offered thematic sightseeing tours of Kraków with a tourist guide covering film issues. All offers were centred around the film Schindler's List (Lista Schindlera) and led through Kazimierz and Podgórze, including in some cases the Liban Quarry, a place where the remains of the film's set can still be seen.

\section{Film tourism events - film festivals}

Based on an analysis of the film industry literature and online sources, seven film-related festivals have been identified in Kraków. The oldest is the Kraków Film Festival (KFF) whose history dates back to 1961 and which operated as the National Short Film 
Festival until renamed in 2001. KFF is one of the oldest festivals in Europe devoted to documentary, animated and short films. Every year, it is visited by nearly 1000 people, and artists compete for awards such as the Golden Horn for the director of the best documentary film, and the Golden Dragon for the director of the best short film. The Kraków Film Festival is one of a distinguished group of festivals accredited by the International Federation of Film Producers (FIAPF) demonstrating the importance of this festival on an international scale (Historia Krakowskiego festiwalu..., 2019).

The Etiuda \& Anima International Film Festival was initiated in 1994 and is considered the oldest such festival in Poland. It is attended by students from film and art schools, as well as creators of artistic animation. Students compete for Bronze, Silver and Gold Dinosaur awards, and the creators of animation for the Gold, Silver and Bronze Jabberwocky awards (Zmudziński, 2017).

In 1996, the Silent Film Festival was begun. From the very beginning, the idea behind it was to distribute and promote silent cinema. It has a unique atmosphere thanks to the live music accompanying film screenings, and by 2019 there were 20 festivals (Historia Festiwalu..., 2019).

In the first decade of the 21st century, the OFF CAMERA International Festival of Independent Cinema was established. Its most important part is its main competition 'Making Way', as well as the Competition for Polish Feature Films. An essential part of the festival is a series of accompanying events, including Miasteczko Filmowe with numerous workshops, meetings and presentations related to film. The establishment of Miasteczko Filmowe is one of the tasks of the 'Film in Małopolska' project implemented under 'Małopolska for Entrepreneurs' co-financed by the European Union under the Regional Operational Program of Małopolskie Voivodeship for 2014-2020 (O festiwalu, 2019).

In 2008, the Film Music Festival was initiated, co-organised by the Kraków Festival Office. During this several-day event in Kraków, film music lovers have a unique opportunity to take part in Film live in concert, presenting well-known film productions accompanied by live music performed by famous musicians and orchestras. The combination and synchronisation of the orchestra in real time with the displayed image, which was the idea of this festival, was also a novelty internationally (Korzeniowski, 2011). The Film Music Festival is a global event that gathers not only fans of this type of music but also attracts artists and people from the film industry. In 2018 it had over 31,000 participants (Raport o stanie miasta 2018, 2019). The 'Audio-visual Forum', an educational platform for young composers, also operates at the festival.

The latest festival initiative is the Kraków International Green Film Festival, which first ran in 2018 and is devoted to ecological issues, taking place in an outdoor Miasteczko Filmowe on Bulwar Czerwiński. In addition to film screenings referring to the most significant environmental problems of the modern world (including climate change, recycling, food waste and the ubiquity of plastic), various types of workshops and thematic campaigns are organised (W Krakowie trwa..., 2019).

Kraków is also one of several cities (including Rzeszów), where the KINOLUB children and youth film festival has been taking place since 2015 and during which professionals award prizes alongside a jury of children and young people ( $O$ festiwalu KINOLUB, 2019). 


\section{Kraków as a film location}

Based on an analysis of the internet database for Polish film, filmpolski.pl, and the Fotote$k a$ website which presents the photographic resources of the National Film Archive's 'Audio-visual Institute', the main film locations in Kraków were selected based on postwar films starting from 1961 (Table 1). Rynek Główny (Main Market Square) with the Sukiennice (Cloth Halls) and the neighbouring Plac Mariacki (St. Mary's Square) are the most frequently chosen places appearing in films made in Kraków, often shown from the perspective of the roofs of adjacent townhouses (Vinci, Entanglement (Uwikłanie)). These places have served as film locations for Indian producers, including in the movies Aazaan and One Love (Jedna miłośc). Filmmakers have also chosen streets within the Old Town: Poselska, św. Jana, Pijarska and Floriańska. In many films, the scenery of Kraków's Planty is found along with the Vistula Boulevards and Wawel Hill. Kazimierz is also noteworthy, although usually associated only with Schindler's List (Lista Schindlera), the charm of this district, especially Szeroka St, has been featured in many other productions (see Table 1). Since the beginning of the 21st century, Nowa Huta has enjoyed great popularity among film producers with this district's unique architectural layout and atmosphere creating the scenery for various genres of film, e.g. fantasy (Avalon), drama (The Coach's Daughter [Córka trenera]) and crime (Dark Crimes).

Table 1. Kraków film locations based on selected feature films

\begin{tabular}{|c|c|}
\hline Film location & Film titles \\
\hline Main Market Square & $\begin{array}{l}\text { Save the City (Ocalić miasto) (1976), } \\
\text { Double Life of Veronica (Podwójne życie Weroniki) (1991), } \\
\text { List of Adulterers (Spis cudzołożnic) (1994), } \\
\text { Street Games (Gry uliczne) (1996), } \\
\text { Angel in Kraków (Anioł w Krakowie) (2002), } \\
\text { Katyń (2007), } \\
\text { Don't Lie, Baby (Nie kłam, kochanie) (2008), } \\
\text { Aazaan (2011), } \\
\text { Entanglement (Uwikłanie) (2011), } \\
\text { Under a Strong Angel (Pod mocnym aniołem) (2013), } \\
\text { Clergy (Kler) (2018) }\end{array}$ \\
\hline St. Mary's Square & $\begin{array}{l}\text { Save the City (Ocalić miasto) (1976), } \\
\text { The Dulski Family (Dulscy) (1976), } \\
\text { Angel in Kraków (Anioł w Krakowie) (2002), } \\
\text { Don't Lie, Baby (Nie kłam, kochanie) (2008), } \\
\text { One Love (2015), } \\
\text { Clergy (Kler) (2018) }\end{array}$ \\
\hline $\begin{array}{l}\text { Cloth Halls } \\
\text { (Sukiennice) }\end{array}$ & $\begin{array}{l}\text { Other Man (Drugi człowiek) (1961), } \\
\text { Double Life of Veronica (Podwójne życie Weroniki) (1991), } \\
\text { Touching the Hand (Dotknięcie ręki) (1992), } \\
\text { Angel in Kraków (Anioł w Krakowie) (2002), } \\
\text { Don't Lie, Baby (Nie kłam, kochanie) (2008) }\end{array}$ \\
\hline Wawel Hill & $\begin{array}{l}\text { The Dulski Family (Dulscy) (1976), } \\
\text { Epitaph for Barbara Radziwiłłówna (Epitafium dla Barbary Radziwiłłówny) (1982), } \\
\text { Touching the Hand (Dotknięcie ręki) (1992), } \\
\text { Small Matura Exam } 1947 \text { (Mała matura 1947) (2010) }\end{array}$ \\
\hline Planty Park & $\begin{array}{l}\text { List of Adulterers (Spis cudzołożnic) (1994), } \\
\text { Angel in Kraków (Anioł w Krakowie) (2002), } \\
\text { Katyń (2007), } \\
\text { Scratch (Rysa) (2008), } \\
\text { Small Matura Exam 1947 (Mała matura 1947) (2010), } \\
\text { Entanglement (Uwikłanie) (2011), } \\
\text { Under a Strong Angel (Pod mocnym aniołem) (2013) }\end{array}$ \\
\hline
\end{tabular}




\begin{tabular}{|c|c|}
\hline $\begin{array}{l}\text { św. Jana (St. John's) } \\
\text { Street }\end{array}$ & $\begin{array}{l}\text { Vinci (2004), } \\
\text { Joanna (2010) }\end{array}$ \\
\hline Floriańska Street & $\begin{array}{l}\text { Vinci (2004), } \\
\text { Aazaan (2011) }\end{array}$ \\
\hline Poselska Street & $\begin{array}{l}\text { Schindler's List (Lista Schindlera) (1993), } \\
\text { Vinci (2004), } \\
\text { Katyń (2007) }\end{array}$ \\
\hline Pijarska Street & $\begin{array}{l}\text { Vinci (2004), } \\
\text { Joanna (2010) }\end{array}$ \\
\hline Barbican & $\begin{array}{l}\text { Yovita (Jowita) (1967), } \\
\text { Small Matura Exam 1947 (Mała matura 1947) (2010), } \\
\text { Bangistan (2015) }\end{array}$ \\
\hline Vistula Boulevard & $\begin{array}{l}\text { Our God's Brother (Brat naszego Boga) (1997), } \\
\text { Angel in Kraków (Anioł w Krakowie) (2002), } \\
\text { Vinci (2004), } \\
\text { Don't Lie, Baby (Nie kłam, kochanie) (2008), } \\
\text { Entanglement (Uwikłanie) (2011), } \\
\text { Red Spider (Czerwony pająk) (2015) } \\
\end{array}$ \\
\hline Skałka & $\begin{array}{l}\text { Ciphers (Szyfry) (1966), } \\
\text { Karol: A Man Who Became Pope (Karol. Człowiek, który został papieżem) (2005) }\end{array}$ \\
\hline $\begin{array}{l}\text { Stadium of FC Wisła } \\
\text { Kraków }\end{array}$ & Jovita (Jowita) (1967) \\
\hline Szczepański Square & $\begin{array}{l}\text { Aazaan (2011), } \\
\text { Entanglement (Uwikłanie) (2011) }\end{array}$ \\
\hline Matejko Square & Vinci (2004) \\
\hline $\begin{array}{l}\text { Kazimierz, Szeroka } \\
\text { Street }\end{array}$ & $\begin{array}{l}\text { Nights and Days (Noce i dnie) (1975), } \\
\text { Schindler's List (Lista Schindlera) (1993), } \\
\text { Happy Man (Szczésliwy człowiek) (2000), } \\
\text { Angel in Kraków (Anioł w Krakowie) (2002), } \\
\text { Vinci (2004), } \\
\text { Don't Lie, Baby (Nie kłam, kochanie) (2008) }\end{array}$ \\
\hline $\begin{array}{l}\text { Kazimierz, Ciemna } \\
\text { Street }\end{array}$ & Angel in Kraków (Anioł w Krakowie) (2002) \\
\hline $\begin{array}{l}\text { Kazimierz, Józefa } \\
\text { Street }\end{array}$ & Schindler's List (Lista Schindlera) (1993) \\
\hline $\begin{array}{l}\text { Kazimierz, plac Nowy } \\
\text { (New Square) }\end{array}$ & $\begin{array}{l}\text { Nights and Days (Noce i dnie) (1975), } \\
\text { Scratch (Rysa) (2008), } \\
\text { Aazaan (2011) }\end{array}$ \\
\hline Podgórze & $\begin{array}{l}\text { Schindler's List (Lista Schindlera) (1993), } \\
\text { Red Spider (Czerwony pająk) (2015) }\end{array}$ \\
\hline St. Benedict's Fort & Red Spider (Czerwony pająk) (2015) \\
\hline Liban Quarry & Schindler's List (Lista Schindlera) (1993) \\
\hline Lasota Hill & Schindler's List (Lista Schindlera) (1993) \\
\hline Zakrzówek & Red Spider (Czerwony pająk) (2015) \\
\hline Kościuszko Mound & $\begin{array}{l}\text { The List of Adulterers (Spis cudzołożnic) (1994), } \\
\text { Quiet Years (Spokojne lata) (1981) }\end{array}$ \\
\hline Main Railway Station & $\begin{array}{l}\text { A Trip for One Smile (Podróż za jeden uśmiech) (1971), } \\
\text { Schindler's List (Lista Schindlera) (1993) }\end{array}$ \\
\hline $\begin{array}{l}\text { Felicjańska and Mała } \\
\text { Streets }\end{array}$ & Under a Strong Angel (Pod mocnym aniołem) (2013) \\
\hline
\end{tabular}




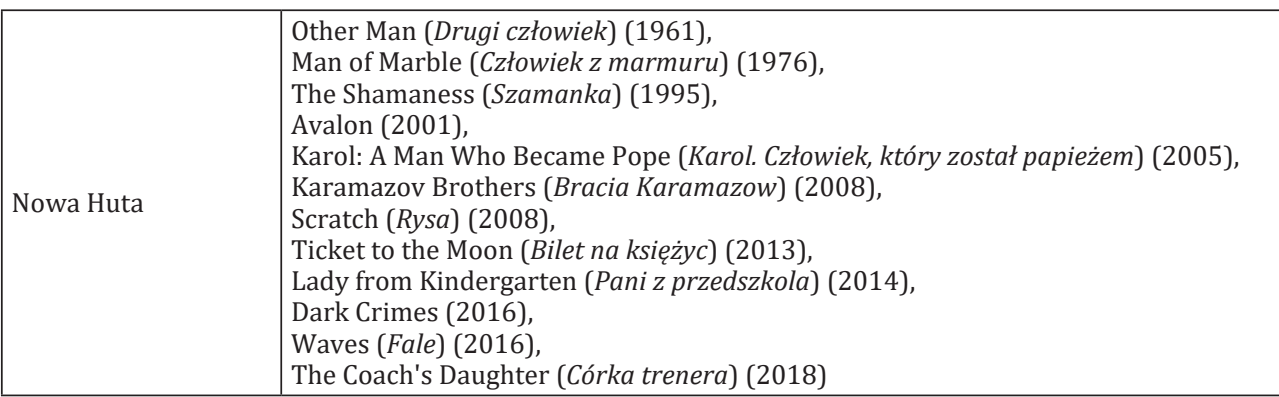

Source: author based on <www.filmpolski.pl> and <www.fototeka.fn.org.pl>

\section{DISCUSSION}

Film tourism takes various forms which is why it should be considered on several levels when discussing development opportunities. Activities taken under the city council strategic documents were considered the first level, and the first research question was associated with them. As the results of the analyses show, these strategic documents recognise the possibility of developing this form of tourism in Kraków, especially for creating new tourism products. However, most of the activities implemented under the Strategia rozwoju turystyki... (2019) concern institutional support for film production, by helping to organise film locations and competitions for funding films. These activities positively affect the promotion of Kraków's image among movie fans, but so far they have not directly been translated into the creation of new tourism products, unlike Torun where thanks to the support of its city council the Torun Film Route has been established (Powstała toruńska... (2019).

The second level on which film tourism in Kraków was considered was an analysis of the content of Kraków guidebooks and promotional materials. As research shows, references to Kraków's film locations in these publications relate primarily to the Oscar-winning Schindler's List (Lista Schindlera) (1993) and Man of Marble (Człowiek z marmuru) (1976). Analysis of guidebook content is rare in the literature, and Ziarkowski (2016) has stated that the importance of guidebook publications is underestimated in academic research, usually limited to factual findings rather than content. Besides, these studies relate in most cases to tourism history. Meanwhile, for a tourist, it is the guidebook that is a source of knowledge about cultural heritage and available sightseeing routes. When answering the second of the research questions posed, it should be stated that content related to films made in Kraków, and suggestions for sightseeing routes related to film, were found in only $15 \%$ of the guidebooks and were devoted to Schindler's List (Lista Schindlera). This result may indicate that the guidebook's authors are not very interested in the film theme and that there is low awareness of the potential for this form of tourism, but it may also result from the lack of an official and well-prepared film route which could be a motivating factor for those who produce the guidebooks.

The third area was the activity of local travel agencies creating guided tours for film in Kraków. As noted by Mikos v. Rohrscheidt (2009), thematisation of the tourist offer, especially in the field of cultural tourism, increases attractiveness for tourists within a given destination and allows organisers to broaden their customer base. When 
answering the third research question, it should be stated that in Kraków there is a negligible percentage of tourist offices (7\%) offering a guided tour devoted to film and it is also worth noting that all current offers concern the film Schindler's List (Lista Schindlera). This situation may arise from the fact that there are several other official thematic routes in Kraków (with varying degrees of popularity) on which travel agencies have built their offer, and they may not see the need to expand them, the more so that it would only be a niche offer to those interested in film heritage. On the other hand, taking advantage of the city's film potential and creating film routes could strengthen their competitiveness on the local market. Among various studies on travel agency offers (Cichoń, 2016; Meyer et al., 2011; Szczechowicz, 2015), it is challenging to find works that deal with quite specific issues about local tourist office services related to a particular region or city. Moreover, although Opas-Zajdlewicz (2017) while researching Szczecin tourist products has drawn attention to the activities of local travel agencies, it is difficult to relate the results of the present work to hers because she focused on socalled tourist packages, not on an offer to explore the city.

When answering the last question regarding prospects for the development of film tourism in Kraków, other elements analysed in this study should be referred to, namely, the main film locations and film festivals. Not without significance in this regard is the intensive activity of institutions supporting productions in recent years (Kraków Film Commission, Regional Film Fund or the International Film Fund), which is consistent with what Roesch wrote (2009) that the potential of film productions should be thought of at the stage of preparation and implementation. In 2018, there were premiers of five films created in co-production with the Kraków Festival Office as part of the Regional Film Fund in Kraków (Raport o stanie miasta 2018, 2019).

The issue of identifying film locations in geographical space is present in Polish literature. Bernat (2016), analysing places chosen as film locations in Lubelskie Voivodeship, drew attention primarily to the features of landscape chosen as locations. Podgórski and Lipowska (2018) undertook to identify the townscapes of the Old Town of Torun in selected film productions and drew attention to the use of film locations in the promotion of the city. As a result of their research, they found that the location of 40 film sets was evidence of the city's attractiveness, and their use in the series Doctors positively affected its recognition. Both Bernat (2016) as well as Podgórski and Lipowska (2018) came to similar conclusions to the author that the existence of places known from films in a city or region has the potential to create various products in the field of film tourism.

A second element in considering the development of film tourism is the functioning of several film festivals in Kraków, and these along with other events affect the perception of Kraków as a city of festivals (Studencka, 2017). The subject of film festivals is often discussed in the literature on film tourism, usually as case studies (Konieczna, 2014; Zmudziński, 2017) or reviews (Ratkowska, 2010). In this article, these events have only been identified to show the city's potential in this sphere. A detailed analysis of the functioning of film festivals in Kraków as a form of film tourism goes beyond the article's scope.

\section{CONCLUSIONS}

Kraków is a city with ample opportunities for the development of film tourism in every aspect, although it should be emphasised that the most significant potential is for film 
tourism events related to participation in film festivals. Considering filmmaking in Kraków, as well as its presence in films of various genres, more than one official film tour could be designed in the city.

The concept of a multifaceted approach to film, and an attempt to assess the opportunities for developing film tourism in a specific area on this basis, is a supplement to the literature on this recent form of tourism. The research results obtained may contribute to the further development of research on various aspects of its functioning, e.g. tourist motivation or interest in other city attractions. In practical terms, the results can inspire those responsible for developing tourism products to create new ways of sightseeing based on film heritage. It is particularly true of film tourism events in which the rich program of festivals goes far beyond the films, and the accompanying events allow film tourists to discover the places where the festivals themselves are held.

\section{References}

Beeton, S. (2005). Film-Induced Tourism: Aspects of Tourism. Clevedon: Channel View, Clevedon, UK.

Beeton, S. (2016). Film-induced tourism. Bristol: Channel View Publications.

Bernat, S. (2016). Film i turystyka filmowa a krajobraz. Prace Komisji Krajobrazu Kulturowego, 34, 85-101.

Buchmann, A., Moore, K., Fisher, D. (2010). Experiencing film tourism: Authenticity and fellowship. Annals of Tourism Research, 37(1), 229-248.

Cardia, G., Jones A., Gavelli, D. (2019). Innovating and Diversifying Cultural Tourism in Europe Through Smart Movie Tourism in UNESCO Sites and Destinations. The Case Study of a Famous Project. W: V. Katsoni, M. Segarra-Oña (eds.) Smart Tourism as a Driver for Culture and Sustainability. Springer Proceedings in Business and Economics. Springer, Cham, 3-14. doi: 10.1007/978-3-030-03910-3_1

Cichoń, P. (2016). Podwieczorek u berbera - gospodarze i goście w świetle turystyki etnicznej. Antropologiczna analiza ofert biur podróży. Folia Turistica, 39, 219-240.

Ciszewska, E. (2016). Postfilmowa Łódź i spojrzenie turysty. Sposoby wykorzystywania filmowych walorów miasta w przedsięwzięciach biznesowych i niekomercyjnych. Panoptikum, 16(23), 205-227.

Connell, J. (2012). Film tourism - Evolution, progress and prospects. Tourism Management, 33(5), 1007-1029.

Connell, J., Meyer, D. (2009). Balamory revisited: An evaluation of the screen tourism destination-tourist nexus. Tourism Management, 30(2), 194-207.

Faber, F., Tomala, K. (2011). Film Tourism, In: A. Papathanassis (ed.) The long tail of tourism: Holiday niches and their impact on mainstream tourism. Wiesbaden: Gabler Verlag, 149-158.

Filmowy Kraków (2019, 10 December). Available: http://www.Kraków.travel/wycieczki/22732

Historia Festiwalu Filmu Niemego (2019, 10 December). Available: http://www.festiwalfilmuniemego.pl/historia/

Historia Krakowskiego Festiwalu Filmowego (2019, 06 December). Available: https://www. Krakówfilmfestival.pl/o-festiwalu/historia/

Joliveau, T. (2009). Connecting Real and Imaginary Places through Geospatial Technologies: Examples from Set-jetting and Art-oriented Tourism. The Cartographic Journal, 46(1), 3645.doi:10.1179/000870409X415570

Kim, S., Reijnders, S. (2017). Asia on My Mind: Understanding Film Tourism in Asia. In: S. Kim, S. Reijnders (ed.) Film Tourism in Asia. Perspectives on Asian Tourism. Springer, Singapore, 1-18. doi:10.1007/978-981-10-5909-4_1

Konieczna, E. (2014). Festiwale i przeglądy filmowe jako cel turystyki kulturowej. Turystyka Kulturowa, 10, 6-18.

Korzeniowski, T. (2011). Festiwal Muzyki Filmowej w Krakowie w latach 2008-2011. Prace Naukowe Akademii im. Jana Długosza w Częstochowie. Edukacja Muzyczna, 6, 217-245. 
Kronenberg, M. (2016). Potencjał turystyczny dziedzictwa filmowego w województwie łódzkim. Łódź: Centrum Inicjatyw na rzecz Rozwoju REGIO.

Lee, Ch. (2012). Have Magic, Will Travel: Tourism and Harry Potter's United (Magical) Kingdom. Tourist Studies, 12(1), 52-69.

Malewski, J. (1996). Pan Tomasz i jego kinematograf. Karta, 20, 108-116.

Marczak, M. (2012). Obraz Warmii i Mazur w polskim filmie fabularnym i serialu: rekonesans. Media - Kultura - Komunikacja Społeczna, 8, 87-115.

Meyer, B., Sawińska, A., Gardzińska, A. (2011). Turystyka religijna jako element oferty produktowej wybranych biur podróży. Zeszyty Naukowe Uniwersytetu Szczecińskiego. Ekonomiczne Problemy Usług, 65, 317-328.

Mikos v. Rohrscheidt A. (2009). Tematyczne podróże po szlakach jako forma turystyki kulturowej. W: K. Buczkowska, A. Mikos von Rohrscheidt (eds.) Współczesne formy turystyki kulturowej, 384-401.

O festiwalu (2019, 30 November). Available: https://offcamera.pl/festiwal/o-festiwalu/

O festiwalu KINOLUB (2019, 25 November). Available: https://kinolub.pl/o-festiwalu/

Opas-Zajdlewicz, I. (2017). Miejsce produktów turystycznych Szczecina w ofertach wybranych biur podróży. Ekonomiczne Problemy Turystyki, 39(3), 155-166.

Podgórski, Z., Lipowska, P. (2018). Krajobrazy Torunia w projektach filmów fabularnych. Prace Komisji Krajobrazu Kulturowego, 40, 47-69.

Powstała toruńska trasa filmowa (2019, 15 December). Available: http://filmcommissionpoland. $\mathrm{pl} / \mathrm{pl} / \mathrm{o}-\mathrm{fcp} /$ aktualnosci/powstala-torunska-trasa-filmowa-htBTty

Raport o stanie miasta 2018 (2019, 10 December). Urząd Miasta Krakowa, Wydział Strategii, Planowania i Monitorowania Inwestycji Oddział Planowania Strategicznego i Analiz. Available: http:// www.bip.Kraków.pl/ l/?dok_id=116634

Ratkowska, P. (2010). O festiwalu w kontekście turystyki kulturowej, czyli turystyka eventową raz jeszcze. Turystyka Kulturowa, 6, 26-46.

Rejestr Organizatorów Turystyki i Przedsiębiorców Ułatwiających Nabywanie Powiązanych Usług Turystycznych Marszałka Województwa Małopolskiego. (2019, 10 December) Urząd Marszałkowski Województwa Małopolskiego (as of February 2019). Available: http://bip. malopolska.pl/

Roesch, S. (2009). The Experiences of Film Location Tourists, Bristol, Buffalo, Toronto: Channel View Publication.

Studencka, K. (2017). A Kraków to... miasto festiwali. Zarzq̨dzanie Publiczne, 37(1), 1-11.

Stasiak, A. (2009). Turystyka filmowa i literacka. W: K. Buczkowska, A.M. von Rohrscheidt (eds.), Współczesne formy turystyki kulturowej. Poznań: AWF w Poznaniu, 223-265.

Szczechowicz, B. (2015). Łączenie wartości turystyki i sportu w świetle analizy ofert rynkowych. In: M. Kazimierczak (ed.) Turystyka sportowa. Społeczno-kulturowy potencjał i perspektywy rozwoju. Poznań: AWF w Poznaniu, 41-54.

Szpara, K. Musz R. (2016). Turystyka filmowa w Sandomierzu. Prace Geograficzne, 145, 31-45.

Śladami Listy Schindlera (2019, 9 December). Available: http://www.Kraków.travel/wyciecz$\mathrm{ki} / 22736$

Tucki, A. (2016). Turystyka filmowa - wybrana problematyka badawcza. Barometr Regionalny, 14(2), 141-146.

Urbańczyk, A. (2019). Studia filmowe i ich rola w kreowaniu wrażeń turystycznych konsumenta In: Z. Młynarczyk, A. Zajadacz (eds.) Uwarunkowania i plany rozwoju turystyki. Planowanie i polityka turystyczna, Turystyka i Rekreacja - Studia i Prace, Poznań, 22, 85-100.

Wilkońska, A. Rotter-Jarzębińska K. (2019, 10 December). Strategia rozwoju turystyki w Krakowie na lata 2014-2020. Kraków: Wydział Informacji, turystyki i Promocji Miasta. Available: http: //www.bip.Kraków.pl/zalaczniki/dokumenty/n/127397/karta

W Krakowie trwa festiwal filmów ekologicznych (2019, 25 November). Available: https://www. Kraków.pl/aktualnosci/232307,33,komunikat,w_Krakowie_trwa_festiwal_filmow_ekologicznych.html

Ziarkowski, D. (2016). Najstarsze polskie przewodniki jako źródła do dziejów turystyki. In: J. Kosiewicz, E. Małolepszy, T. Drozdek-Małolepsza (eds.), Z dziejów wychowania fizycznego, sportu i turystyki $w$ Polsce $i$ w Europie. Częstochowa: Akademia Jana Długosza w Częstochowie 265-279. 
Zmudziński, B. (2017). Festiwal Etiuda\&Anima, czyli filmowe święto (z doświadczeń własnych autora). Kwartalnik Filmowy, 100, 22-33.

Zmyślony, P. (2001). Wpływ sztuki filmowej na rozwój nowych produktów turystycznych w Polsce. Problemy turystyki, 3-4, 21-30.

Anna Kolasińska, assistant professor/PhD Pedagogical University of Kraków, Institute of Geography, Department of Tourism and Regional Studies Poland. PhD at the Pedagogical University in Kraków and Kraków tourist guide. Her research area includes the issues of the tourist use of valuable natural areas, in particular the impact of tourism on national parks, as well as issues related to cultural tourism in Kraków.

ORCID: 0000-0001-6990-0128

\section{Address:}

Uniwersytet Pedagogiczny w Krakowie Instytut Geografii

Katedra Turystyki i Badań Regionalnych ul. Podchorążych 2, 30-084 Kraków, Polska

e-mail: anna.kolasinska@up.Kraków.pl 